\title{
The Justice System in Albania - Analysis of Progress Report 2016
}

\section{Gerta Hasmuça}

PhD Candidate, University of Tirana, Institute of European Studies

\section{Doi:10.5901/mjss.2017.v8n1p180}

\section{Abstract}

\begin{abstract}
Albania is one of the new democracies in the South-Eastern Europe which hopes to be granted the status of membership to the European Union. Since June 2014, Albania is a candidate for accession to European Union, after it fulfilled the requirements based on Stabilization and Association Agreement the negotiations of whom started in 2003 and was signed in 2006. Even though the formal application of Albania is dated in 2009, the country has undergone through a difficult process in order to fulfill the pre-requirements especially in the justice system in Albania. The level of corruption is considered the main problem which was highlighted also in the other Progress Reports of Albania and it is still considered to be an important impediment to Albanian accession to EU. Differently from the other progress reports, in the progress report 2016 (Albania 2016 Report), there are noted some improvements consisting mainly in the adoption of a set of constitutional amendments which was the starting point to thorough justice reform. Even though initially such process was faced with the severe diversion of opinions of Albanian main parties, they finally reached an agreement with the recommendations provided by the Venice Commission at the Council of Europe. The report considers as a positive step the newly adopted law on the re-evaluation of judges, prosecutors and legal advisors. Another positive aspect of the law is the re-evaluation (vetting) based on 3 criteria: integrity through assets assessment, background assessment (inappropriate links with organized crime) and professional competence. Such improvements weren't sufficient enough to permit to Albania to start negotiations with EU as there are still many obstacles to overcome.
\end{abstract}

Keywords: Albania, Justice System, EU membership, progress, assessment.

Even though Albania is situated in the south-eastern Europe in the eyes of the rest of Europe seems as isolated in one hidden side of Europe which looks as invisible to them. Many Europeans don't even know that Albania is in Europe. This is because it has always been considered as just a poor country in Europe but no doubt everyone knows very well our neighbors Greece, Italy, Former Republic of Macedonia and Montenegro and even Kosovo which was cut off from Albania after the First World War. A lot of foreigners, who have been working in Albania, are aware of its beautiful beaches even though not very much invested are far more beautiful than Greek's or any other country which are popular and visited by many tourists. But the beauty of Albania is not just the coast but also known for the natural beauty of our lakes as well as the antiquity of different cities in Albania which are very old. Albania looks as a destination still to be discovered. Nobody knows our history, our traditions and sacrifices that Albanians have done during the centuries to survive in front of potent countries eager to have a slice of its territory. Why big investors aren't coming to Albania? It is just because of the judicial system that is corrupted and they don't want to risk their investment.

Still, people, who have no information about Albania, used the little information they had about Albania as an excuse that if UK stays in EU, it will allow all Albanian criminals to enter the UK territory. Even though corruption is a widespread concern for Albanians, such information cannot be taken for granted for two reasons: firstly, not all Albanians are criminals and secondly, just the visa cannot limit criminals enter the UK border. For sure the part of population who didn't enter the UK border is the intellectual part, the ones who decided to work for their own country, the ones who are decided to fight for Albania in order to have the same standards like other European countries.

Being a new democracy which is dated in 1991 with the communism fall, Albanians are still fighting for such democracy in the full sense of it. Same as all communists countries in the Balkans, the establishing of democracy in the country played an important transforming impact in the whole life comprising politics, many political parties were created for the first time, economic, for the first time Albanians were faced with trade market as a result of which people were not equal any more. Some of them were poor and some very rich which is actually the same in Albania. But Albania was different from other countries; our communism system was very rigid and very harsh. The restoration of democracy provided not just more money circulating to people but also the corruption. A new notion which entered in the countries life, corruption entered in all the most important aspects of life such as health sector, justice system etc. which caused considerable damage to population. 
With the fall of communism, Albania started to restore good relations with all the other countries with which were interrupted for a long time and putting an end to the isolation of the country. As step by step, the economy was improving, the laws were written from the very beginning following the model of European countries and the legal system was based on common law system.

With the restoration of the good relationship with western European countries, Albania started the long and difficult process of striving to be part of the EU. After the communism fall, Albania for the first time was collaborating with other European countries. In 1991, many Albanians who left their country immigrated and found refuge in Italy and Greece, the two EU countries close to it which was the first real contact of Albanians with European countries.

The close collaboration between Albania and EU is dated in 1992 with the Trade and cooperation Agreement which allowed Albania to be eligible for funding under EU Phare programme. An important aspect of this relationship is the Stabilization and Association Process (SAP) which the EU proposed in 1999 for five countries of South Eastern Europe, including Albania. The negotiations for SAA after the recommendation of the Commission in 2001 were launched on 31 January 2003 and signed on 12 June 2006. The visa facilitation signed on 13 April 2007 and entering into force on 1 January 2008 was an important phase of the collaboration between Albania and EU. In November 2010, Albania as well as other countries in the region was granted the visa liberalization. For the first time Albanians could travel to Schengen countries without waiting in long queues and feeling the long and difficult path we have in front of us in every aspect of life.

The Albanian application for EU Membership was submitted in 2009 and the response it received from EU is 12 recommendations which Albania had to fulfill in order to start negotiations, provided by the European Commission on 9 November 2010. The twelve recommendations were the following:

- Ensure the proper functioning of Parliament on the basis of a constructive and sustained political dialogue among all political parties.

- Adopt pending laws requiring a reinforced majority in Parliament.

- $\quad$ Appoint the Ombudsman, and ensure an orderly hearing and voting process in Parliament for constitutional and high court appointments.

- $\quad$ Modify the legislative framework for elections in line with OSCE-ODIHR recommendations.

- Ensure elections are conducted in line with European and international standards.

- Complete essential steps in public administration reform including amendments to the civil service law and strengthening of the Department of Public Administration, with a view to enhancing professionalism and depoliticization of public administration and to strengthening a transparent, merit-based approach to appointments and promotions.

- Strengthen rule of law through adoption and implementation of a reform strategy for the judiciary, ensuring the independence, efficiency and accountability of judicial institutions.

- Effectively implement the government's anti-corruption strategy and action plan, remove obstacles to investigations, in particular of judges, ministers and Member of Parliaments; develop a solid track record of proactive investigations, prosecutions and convictions in corruption cases at all levels.

- Strengthen the fight against organized crime, based on threat assessment and proactive investigation, increased cooperation with regional and EU partners and better coordination of law enforcement agencies. Develop a solid track record in this area.

- Prepare, adopt and implement a national strategy and action plan on property rights following broad stakeholder consultation and taking ECtHR case law into account; this should cover restitution, compensation and legalization processes.

- Take concrete steps to reinforce the protection of human rights, notably for women, children and Roma, and to effectively implement anti-discrimination policies. - Take additional measures to improve treatment of detainees in police stations, pre-trial detention and prisons. Strengthen the judicial follow-up of cases of illtreatment and improve the application of recommendations of the Ombudsman in this field.

In the progress report on Albania of 2012, the EC recommended that Albania be granted a conditioned candidate status and it was only in 27 June 2014 that Albania was granted the status of EU Candidate. This was due to efforts made by the Albanian government to fulfill the requirements set by the EC.

Out of the above-mentioned 12 requirements just five of them remain to be fulfilled by Albania in order to start the negotiations. Even through the remaining requirements set by the EC are equal in importance, the judicial system is the most problematic. The most important requirement that Albania had to fulfill is the judicial reform which was finally approved in Albanian Parliament in $\mathbf{2 0 1 6}$ after many long discussions between the two main parties as well as the interference of USA Ambassador in Albania and EU Ambassador in Albania. The main reason by the EC, as well as other 
diplomatic representations in Albania was to put an end to corruption in Albania which is more problematic in the justice system. It is not only one of the main conditions to be fulfilled by Albania but it is also considered a great obstacle to be granted the status of an EU Member State.

Corruption in Albania was analyzed by many other diplomatic representatives who insisted in providing valuable advice to Albanian government with regards to judicial reform. One of them is Mr. Stephen Hickling, charge d'affaires a.i. of the British Embassy.

Concerning the corruption in the public consultation of "Analysis of the Justice System in Albania-2015" document, Mr. Stephen Hickling, highlighted that the judicial reform is very important for several reasons mainly because of the Albania's EU membership as well as the foreign investments. He mentioned as well that corruption in the judicial system is causing the cancellation of many projects by the foreign investments and other investors don't want to risk. Mr. Hickling didn't blame just the judges for corruption and bribery; he blamed also the lawyers and others in the legal services as complicit benefiting from the system. He also stated that since judicial reform is a major issue facing Albania, all parties have a responsibility to play their role.

As the Secretary of the Venice Commission to Council of Europe, Thomas Markert stated in 2016, the judicial reform is in the interest of Albanian citizens and it shouldn't be seen as an EU obligation in the European integration process of the country. He also states that the main thing is the independency of judiciary, to increase accountability and efficiency of the fight against corruption. ${ }^{1}$

For the first time, Progress Report 2016 mentions that some progress was achieved in the Judiciary and fundamental rights. Based on this report, such achievements are related to the justice reform process. But even though such reform was approved in parliament, the report says that corruption remains prevalent in many areas.

Regarding the independence and impartiality, the Report highlights the fact that the judicial system remains seriously affected by politicization, corruption and weak inter-institutional cooperation. Even though the justice reform aims to increase the independence, impartiality and transparency of judicial bodies, it still remains an important step the implementation of such reform. The opinion provided by the Venice Commission in March played a crucial role in the drafting of judicial reform. It was in fact the only version on which the two main political parties in Albania agreed and as a result, approving it with the majority of votes in Parliament. The Report mentions as pending work 40 legislative texts, including amendments to codes which are being prepared.

Regarding the accountability, the report mentions that the frequent hearings held in judges' offices enable potential undue influence and corruption. Another problem mentioned in the report is disciplinary proceedings against six judges which ended up with one dismissal from office and a transfer to another court and another one appealed his dismissal to the High Court. Two main concerns which are highlighted in such case are the facts that there is lack of transparency in handling disciplinary proceedings and the website set up last year by High Court of Justice to file and monitor complaints against judges is not operational.

Regarding the General Prosecutor's Office, the Report mentions highlights the lack of transparency in handling the appointments requests for disciplinary proceedings and decisions on dismissals as well as lack of overall accountability.

Concerning the quality of justice the Report estimated as positive that the School of Magistrate increased its inservice training of EU acquis but it still considers the need for improvement with regards to budget planning capacity and adequate budgetary resources for the justice system as well as need for improvement lacks human resources and adequate infrastructure.

A positive thing is considered also the installation of audio recording system in almost all first instances and appeal courts but remains a problem the short-comings which affect ICMIS electronic court case management system which should ensure random, transparent and balanced allocation of cases to judges in all courts.

The report estimates as positive the fact that the case management system for prosecution service has been implemented in 20 prosecution offices but at the same time it considers as negative the fact that it is not fully operational in some offices and problematic are considered working and security conditions which are not ensured.

In addition, the report highlights the problem of online access to jurisprudence which has to be ensured and improvement should be made in appropriate grounds of court ruling as well as meeting publication deadlines.

The report mentions as a positive and important step the issuance of new mediator licenses which reached the total number of licensed mediators to 467 against 367 in 2015. Even though it is considered as positive, the report notes the fact that just 63 mediators are actively working limiting in this way the mediation provided.

Regarding the corruption, the report marks some improvements regarding the increase of number of convictions for junior and middle ranking officials from 103 in 2014 to 286 in 2015. A positive fact is considered as well the conviction

${ }^{1}$ http://shtetiweb.org/2016/01/24/komisioni-i-venecias-reforma-ne-drejtesi-ne-rrugen-e-duhur/?print=pdf 
of one lawyer and one judge in 2015. Another important positive fact is also considered the conviction of a former minister and one prosecutor.

The report mentions as well a positive fact that in 2015 out of 75 criminal referrals submitted to prosecutors, 26 cases involved high state officials. It also stresses as positive the cases of three persons in 2015 , who were convicted for issues related to assets declaration. Another positive fact is considered the 20 cases submitted to prosecution service in the first half of 2016, eleven of which involved Heads of Communes, seven of whom were found guilty. In addition, another positive fact is mentioned is the 51 cases that High State Audit referred to prosecution concerning 156 officials about the misuse of the state budget.

Although the report noted a positive improvements in the corruption of the judicial system, it also recommends that HIDAACI should further strengthen its administrative, technical and financial capacity and as well as to strengthen the role of HAS in the overall anti-corruption framework. The report points out as positive the increase of the use of audit and inspections in the tax and customs services but it as well highlights that addressing the corruption in the tax and customs administration is still problematic.

\section{Conclusion}

Even though the report highlights that Albania has made further improvement with regards to the requirements set by the EC in order to be an EU Member State, it still needs to make fundamental improvements such as the implementation of the Judicial Reform which would finally allow politicians and judges be punished in case of corruption and/or different offences.

In the Progress Report 2016 Albania, EC considered as a very important step the approval of such an important reform in Albania by the main political parties in the country. After the approval of the reform, it was submitted to Constitutional Court in Albania by Democratic Party remaining pending until the final recommendations of such court.

An important aspect of such pending case is the non-collaboration between the two main parties in Albania. On one hand they are avoiding the implementation of such reform by not allowing the corruption be punished and causing indirectly the non-integration of Albania into the European Union.

The report mentions that many improvements need to be made in the judicial system but vetting the evaluation of judges and prosecutors to be adopted within the framework of Judicial Reform is another crucial aspect of such reform. The EU Ambassador in Albania recently stated that the vetting is not to be negotiated.

In order to have further improvements which would allow Albania to start the negotiations with EU, the main political parties should collaborate closely so that corruption level is diminished and the judicial system can punish not only the senior state officials but also corrupted judges as well as politicians.

If we fulfill such a requirement set to Albania, will we be considered to be an EU Member State? Even if we do, I think it will require a lot of time to be implemented. Will the reform destroy all the corruption chain in Albania? I still think that it would be difficult to cut such chain but if it is done, I agree that it should start from the very top of the hierarchy.

\section{References}

Progress report 2012 Albania

Progress report 2016 Albania

http://shtetiweb.org/2016/01/24/komisioni-i-venecias-reforma-ne-drejtesi-ne-rrugen-e-duhur/?print=pdf

https://www.gov.uk/government/world-location-news/analysis-of-the-justice-system-in-albania-2015

https://www.consilium.europa.eu/uedocs/cms_data/docs/pressdata/en/jha/117555.pdf 